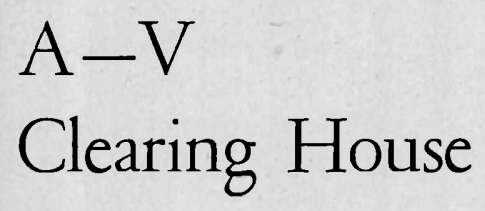

Edited by the

ACRL AUDIO-VISUAL

COMMITTEE

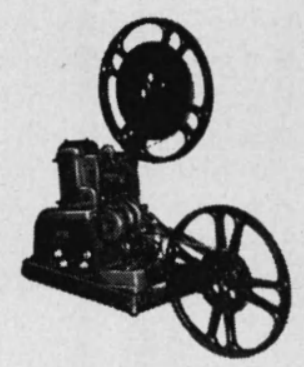

No. 5

Louis Shores, Chairman; Fleming Bennett; Jane Culler; Budd Gambee; John Harvey; Margaret I. Rufsvold; Walter Stone.

\section{Aunio-Visual Equipment}

By Otis McBride

Director, Audio-Visual Center

Library School, Florida State University

W HAT'S HAPPENING WITH A-V EQUIPMENT? In the space of an A-V Clearing House not too much can be said; but it might be well to run down the line arbitrarily, pick some of the most-used types, and list some of the characteristics and special features. For fuller information see Edward F. Ahrendt, editor, The Audio-Visual Equipment Directory, National Audio-Visual Association, Evanston, Illinois, 1955. Some of the information in this report was collected through reference to the NAVA Directory, for which grateful acknowledgment is hereby made.

Suppose we hold to some six main categories, with mention at the end of special or unusual developments of recent times.

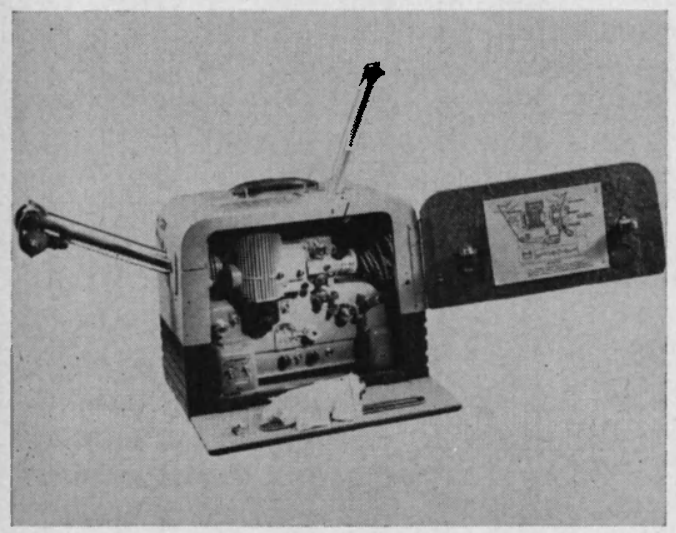

$16 \mathrm{~mm}$ Motion Picture Projector (Bell and Howell Film-O-Sound 385-C Specialist)

\section{I6MM SOUND MOTION PICTURE PROJECTORS}

These get better and better. The addition of such things as longer film shoes, simple rewind procedures, automatic loop setters, sapphire parts, etc., make for greater ease of operation and longer life. Sound systems are being made larger and more adequate. Because of space limitations, only five projectors will be listed. There are many more.

Bell and Howell Film-O-Sound Specialist 385. The new Bell and Howell Specialist 385 has a 15-watt amplifier instead of 10 as in the former model and an 8-inch speaker instead of a 6 . The automatic loop setter has proved to be quite a convenience, rather consistently resetting the loop without need for stopping the machine. A new all-aluminum blimp has been designed, more effectively to cut out machine noise.

Model CR, $\$ 479.95$

Amplifier 15 watts

Reverse and still picture

Radio Corporation of America

Model 400 Junior, $\$ 475$

Amplifier 10 watts

No reverse and still picture

Eastman Kodak Company. Features a new shutter. When the projector is started the shutter, which has three blades, immediately reduces to two, thus increasing materially the amount of light.

Model: Kodascope Pageant, AV-073, $\$ 425$

Amplifier 7 watts

No reverse and still picture

Technical Service Incorporated. Has a special ingenious mirror and small screen arrange- 
ment to do rear projection on its own screen, 135 square inches, or on regular screen. Small screen gives good results in lighted room.

Model: Duolite DU-5, $\$ 498$

Amplifier 5 watts

No reverse and still picture

Lenses: $2^{\prime \prime} \mathrm{f} / 1.6$ and $5 / 8^{\prime \prime} \mathrm{f} / 2.0$

Victor Animatograph Corporation. Two features of the Victor are the 180 degree swingout lens and the single drive sprocket which controls the film entering and leaving the projector.

\section{Model: Assembly 10, $\$ 447$ \\ Amplifier 10 watts \\ Reverse and still picture}

\section{MAGNETIC SOUND MOTION PICTURE PROJECTORS}

Still greater usefulness is brought to the educational film by the magnetic sound projector. A film may be sound-striped, the stripe being placed beside the optical track, and either can be used. The magnetic track has the same flexibility as a tape recorder. Teacher and pupils may make up their own narration and change it at will. Film production can be greatly aided by the magnetic striping.

The magnetic equipment adds approximately 50 per cent to the cost of the projector. Though you may feel that you cannot af ford to own one until they are more widely used and more universally available, they are doubtless here to stay and will be available at a later date, as they add appreciably to the usefulness of films. Most of the companies make special magnetic projectors or attachments to convert standard projectors to magnetic.

\section{THE OPAQUE PROJECTOR}

Most people seem to agree that this is the most versatile piece of equipment of all. It requires more darkening than others, as opaque materials do not reflect much light. But the room does not have to be pitch dark! What a convenience it is to be able to show the composition of one student to a whole class. The shorthand teacher, the art teacher, the math teacher will find many uses for the opaque. The sewing student may sketch her dress eight inches in over-all height and then blow it up to actual size with the opaque be-

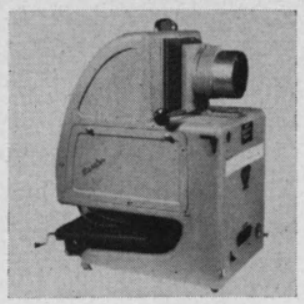

Opaque Projector (Vu-Lyte II, Charles Beseler Company) fore beginning work on a pattern. Many are the uses! Most models have special features such as built-in pointers and automatic feed.

Charles Beseler Company. The new Beseler Vu-Lyte II is about the same weight and size as former models. Though it uses the same 1,000 watt lamp as previous models, it develops about twice as much light, a dramatic improvement. Much less darkening is needed. Cooling, unfortunately, is about the same as in former models.

Model: Vu-Lyte II, $\$ 249$ (without automatic feed and built-in pointer)

Aperture 10" $\times 10^{\prime \prime}$

\section{American Optical Company}

Model AO Opaque 1000, $\$ 255$

Aperture $10^{\prime \prime} \times 10^{\prime \prime}$

Squibb-Taylor, Inc.

Model TS-3, $\$ 287.50$

Aperture 10" $\times 10^{\prime \prime}$

Charles Beseler Company. We bought one of these and call it "Little Henry." It has a small lamp, only $5^{\prime \prime} \times 5^{\prime \prime}$ aperture, and you have to pick it up and place it over the work. But it does a good job. If your school does not happen to have $\$ 275$, for $\$ 32.25$ it will go a long way toward convincing a superintendent or administrator what the opaque will do and why it is needed. Then you could talk about getting a larger, more versatile and more adequate machine.

Model O, No. 2003, $\$ 32.25$

Aperture 5" x 5"

Weight, 9 lbs.

\section{THE OVERHEAD PROJECTOR}

The overhead projector provides light underneath the transparency which reflects the image into the lens above. A mirror reflects this image at right angles onto the screen, thus the instructor may look directly at the work he has placed on the aperture, while the students see it on the screen behind him. He may even write with a grease pencil on a cellophane sheet drawn across the aperture, 


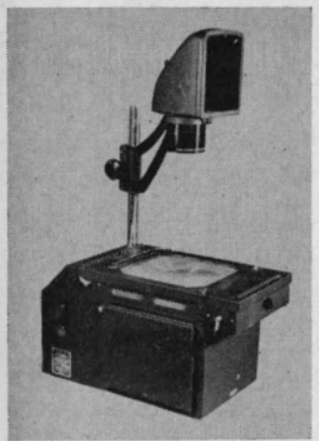

Overhead Projector (Master VuGraph 3900, Charles Beseler Company)

the writing appearing on the screen behind him. A finger or a fountain pen will serve quite well as a pointer. Thus the teacher may concentrate on his work, facing the class, without the inconvenience of constantly turning to look back at the screen. This is not an opaque projector. The material must be transparent. But material ranging in size from about a $31 / 4^{\prime \prime} \times 4^{\prime \prime}$ slide up to $10^{\prime \prime} \times 10^{\prime \prime}$ (if the overhead is the large type) can be handled with ease.

\section{Charles Beseler Company}

Model: Master Vu-Graph No. 3900, $\$ 295$ Aperture 10" 10 10"

Keystone View Company. This projector is primarily for $31 / 4 "$ x $4^{\prime \prime}$ slides. It will take other transparencies up to those dimensions.

Model 1045, \$184

Victorlite Industries, Inc.

Model: VisualCast Challenger, Type TA-C, $\$ 274$

Aperture, circular, $9^{\prime \prime}$ in diameter

Charles Beseler Company. This little fellow is brand new. It will project transparencies up to $5^{\prime \prime} \times 5^{\prime \prime}$. The machine folds compactly, over-all size and case being $10^{\prime \prime} \times 181 / 2^{\prime \prime} \times 8$ ", and weight is only $161 / 4$ lbs.

Model: Vu-Graph 55, \$155

\section{COMBINATION FILMSTRIP AND 2" $x$ 2" PROJECTORS}

Because of the popularity of filmstrips and 2 " $\times 2$ " slides, competition has been keen in this area. 'Most families now contain at least one camera-bug, so that $2 " \times 2$ " slides and filmstrips can be produced at home, with subjects of your own choosing, and even in beautiful color. Classroom projectors have lamps of 300 to 750 watts. Five hundred is enough for large classrooms and will make possible showings with almost no darkening. Practically all these projectors intended for

classroom use at all are in combination, $2^{\prime \prime} \mathrm{x}$ 2 " slides and filmstrips. It would be questionable procedure to

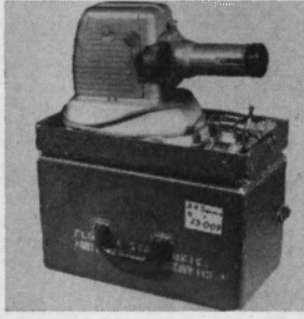

Filmstrip and 2" $\times 2$ " Projector (Viewlex $V$ 25CL) wattage will be given. Many other models and makes are available.

\section{American Optical Company}

MC, No. 3800 (300 watts) , $\$ 92$

Educator 500, No. 3824 (500 watts) , $\$ 103.50$

\section{Eastman Kodak Company}

Signet 300 (300 watts) , $\$ 85$

Signet 500 (500 watts), $\$ 98$

\section{Society for Visual Education}

Instructor 300 (300 watts) , $\$ 89.50$

Instructor 500 (500 watts), $\$ 109.50$

Three Dimension Company (Division of Bell and Howell)

224 Schoolmate (300 watts), $\$ 59.75$

124 Schoolmate (500 watts), $\$ 75$

Viewlex, Inc.

V22GL (300 watts), $\$ 86.75$

V25CL (500 watts), \$104.75

\section{SOUND FILMSTRIPS AND 2" x 2" SLIDES}

It is certainly my prediction that we shall see more and more sound filmstrips and 2" $\mathrm{x} 2$ " slides. All that is necessary is that a disc or tape be made to carry the narration with an appropriate signal (small chime, pencil tapped on desk, or something) to let the operator know when to move to the next frame or slide. Narration, if a tape recorder is available, can be made by the teacher or the students.

Equipment necessary. No particular purpose is served by having a recorder and projector built into each other. You need both. Buy them separately and use them together 
any time your filmstrip has sound. Then when you have a silent filmstrip or a set of slides, the tape or disc playback can be made available to some other user.

\section{TAPE RECORDERS}

There are lots of these. Recorders are beginning to appear now with multiple speakers built in ("tweeters" and "woofers") and

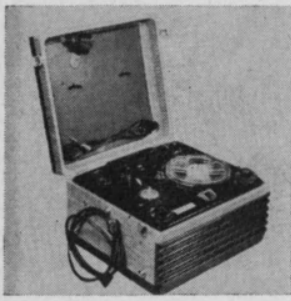

Tape Recorder (Webcor 2110) a range that makes possible rather high fidelity. Tapes are now stronger and brakes on recorders greatly improved, so that tape breakage rarely occurs. New machines are available that reverse, recording or playing back, either to the left or to the right, on opposite edges of the tape, without the necessity of the reel's being lifted and turned over.

If you can afford such, footage counters are available at slight extra cost. They are quite a convenience, as nobody has figured out a good way to "find your place" in the tape otherwise. If, for example, a 1200 foot tape has a selection from Bach in it that you want to use, you may determine ahead of time that it starts at 758 feet. When it is needed, run the tape to that point, as indicated by the counter, and proceed. Any number of spots can thus be found quickly and easily.

Most new records have fast-forward or reversing equipment. Many have multiple speeds, $33 / 4$ and $71 / 2$, or $71 / 2$ and 15 inches per second. Here is some information on a few.

\section{Ampro Corporation}

Model $757 \mathrm{hi}-\mathrm{fi}, 33 / 4$ and $71 / 2, \$ 239.95$

Bell and Howell Company

Model: Specialist $300-S, 33 / 4$ and $71 / 2, \$ 299.50$

Magnecord, Inc.

Model M-30, 33/4 and 71/2, $\$ 299$

Webster Chicago Corporation (Web-Cor)

Model: Webcor 2110, 33/4 and $71 / 2, \$ 209.95$

\section{Wilcox Gay Corporation}

Model: Recordio 4A10, j3 $3 / 4$ and $71 / 2, \$ 149.95$

\section{RECORD PLAYERS}

Of course, a large number of record players, even "home-type" record players, will serve quite satisfac-

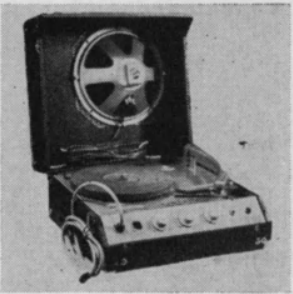

Record Player (Newcomb $R$-16) torily, except that it would seem pointless to spend money for a beautiful wood cabinet to be carted a round for school use. Three speeds are essential. The dual needle set-up is necessary because the blunt needle used for 78 r.p.m. standard recordings will not fit in the $331 / 3$ r.p.m. microgroove records. The five record players listed below all offer speeds of 78, 45, and 33 1/3 r.p.m. and have turnover cartridges with two needles. They are self-contained, each having its own speaker. Many models are available to play through a radio or separate amplifier and speaker.

\section{Audio-Master Corporation}

Model A-M, No. 53-PA, $\$ 89.50$

Record size, up to $171 / 4$ "; 12 " speaker in detachable cover

\section{Califone Corporation}

Model 16VP2-5 Quartet, $\$ 139.50$

Record size, up to $16^{\prime \prime} ; 12$ " speaker in detachable cover

4 speeds plus variable

\section{Magnavox Company}

Model P-50 Classmate, $\$ 85$

Record size, up to $12^{\prime \prime}$; two built-in 6" speakers

\section{Newcomb Electronics Corporation}

Model R-16, $\$ 115$

Record size, up to $171 / 4$ "; 10 " built-in speaker

\section{Webster-Chicago Corporation}

Model: Webcor Maestro 1134, $\$ 54.50$

Record size, up to $12^{\prime \prime} ; 6^{\prime \prime}$ built-in speaker

\section{THE FUTURE}

Many new things in the audio-visual field are in the offing. Perhaps a few are worth mentioning. 
Dramatic developments are being announced constantly in new films. The Tri-X film is faster now than any film that has been before us in film history. Still in the midst of experimentation, emulsion speeds have been found that range from 200 past the capacity of present day light meters. Color is coming in for its share of attention and speed and ease in handling are being increased.

Xenon light, now too expensive for most users, will probably be released in the near future for $16 \mathrm{~mm}$ and perhaps other types of projection.
The anamorphic lens, which is of course a by-word in $35 \mathrm{~mm}$ commercial movies, is coming into wider use and fuller recognition in the $16 \mathrm{~mm}$ field. A number of lenses are on the market for use with cameras in $16 \mathrm{~mm}$ cinematography. Recently entertainment films became available for use with the anamorphic lens and wide screen.

Equipment is coming out in larger and larger quantities, more streamlined, more adequate, more serviceable. Watch for it!

\section{U. S. Steel and Remington Rand Grants to Libraries}

Two important grants totalling $\$ 35,000$ have been received by the American Library Association for the Association of College and Reference Libraries program of grants for college libraries.

The United States Steel Foundation has allocated $\$ 30,000$ to ACRL to strengthen college and university libraries by improving their collections, equipment and programs as adjuncts to the teaching and learning processes. In making this grant, Roger M. Blough, Chairman of the Board of Trustees of the Foundation, stated that "the Foundation was pleased with the results of the initial grant made to the Association last year and desired to continue participation in the plan by which modest aid is provided to scores of colleges for improving their libraries as important adjuncts to teaching." Loyal members of ACRL will appreciate these words of praise for the handling of last year's grant as well as the continued financial support. The Association has wide latitude in the use of the grant. It is expected that distribution of the money this fall will follow the same general policy used in 1955 .

Remington Rand has likewise granted the Association $\$ 5,000$ for the ACRL program of foundation grants. The money will be used to make approximately 8-12 grants to college libraries for equipment. Remington Rand is a division of Sperry Rand Corporation, but is better known to librarians for its Library Bureau.

These grants, as well as the New York Times grant previously announced, are primarily for the benefit of four-year, non-tax-supported colleges and universities. The September issue of College AND RESEARCH LIBRARIES will carry a full statement on all grants available, the purposes for which they will be disbursed, the general policy of ACRL's Committee on Foundation Projects in making grants, and the procedure of application. Readers are urged not to apply for further information until this statement has appeared. The application forms will be mailed out to librarians in October. No action will be taken on applications until the middle of November. The distribution of funds should be completed on or about the end of the year.-Arthur T. Hamlin. 


\section{Personnel}

First woman to hold the position of librarian at Oberlin College will be EILEeN THORNTON of Vassar who will succeed JULIAN S. Fow L E R. M is S Thornton will assume her duties at Oberlin on January 1, 1957.

Irish-born, Miss Thornton was graduated from the University of Minnesota and received the A.M. degree from the University of Chicago. She has been librarian at Vassar since 1945 , following three years as college

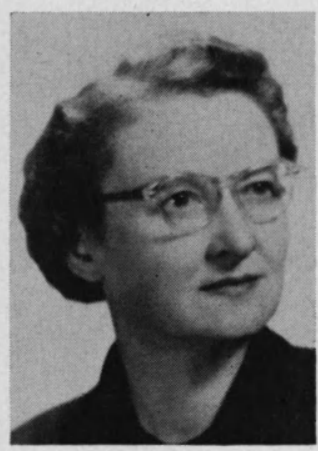

EILEen ThoRnton librarian and administrative assistant at the University of Chicago. Prior to that she had held various library posts at the University of Minnesota, the Hibbing Public Library, and at other places in the Midwest.

Last year Miss Thornton was college library consultant for the Division of Higher Education of the New York State Education Department. In the summer of 1953 she taught two courses at the Western Reserve University School of Library Science and in 1949 she directed a summer workshop on college libraries at Columbia University's School of Library Service.

Miss Thornton has been an officer or national committee member of various organizations frequently over the years and is, at present, vice-president and president-elect of the New York Library Association.

Editor's Note: As this issue goes to press, official news of Miss Thornton's election as first vice-president and president-elect of ACRL has been received.

The biographical information on James SKIPPER which accompanied the notice in the May C\&RL of his appointment as assistant librarian in charge of technical services at Michigan State University was in error. Formerly acquisition librarian at Ohio State University, Mr. Skipper did his undergraduate work at the University of North Carolina. He received his bachelor's and master's degrees in library science at the University of Michigan, where he is now working on his doctorate.

The librarian whose career was described under Mr. Skipper's name is HenRy Koch, whose appointment as divisional librarian in the Social Science and Literature Room at Michigan State University was announced in the March issue of C\&RL.

Forrest Palmer, for five years on the staff of the North Carolina State College Library, left Raleigh last September to become Director of Libraries at Mississippi State College. Mr. Palmer, a native of $\mathrm{Wisconsin}$, did his undergraduate work at Valparaiso where he received his B.A. in 1948. He received his B.S. in L.S. at George Peabody in 1949 and his M.S. in L.S. at the same institution in 1953.

Mr. Palmer came

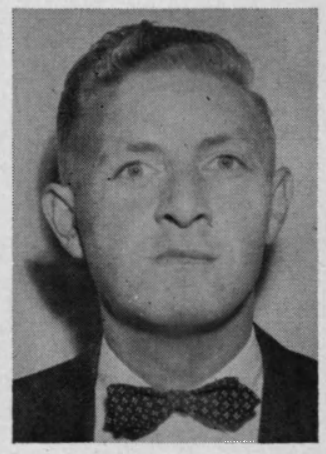

Forrest PaLMER to N.C. State in 1950 as serials cataloger at which position he worked for one year, becoming serials librarian in 1951 and remaining in that position until his departure.

During the period of his stay at North Carolina State College, Mr. Palmer participated in the planning of a new library building and remained to observe the results of his planning and to make use of the areas in which his work was concerned.

He represented North Carolina State College in the preparation of the "Checklist of Scientific Periodicals," a finding list of scientific periodicals and serials in the Libraries at Duke University, North Carolina State College, University of North Carolina, and Woman's College of the University of North Carolina. This was published in 1954.

North Carolina State College at Raleigh regrets the loss of Forrest Palmer and salutes Mississippi for its fortune in securing the services of an excellent librarian.-Harlan $C$. Brown. 


\section{Appointments}

J. Archer Eggen is the librarian of the St. Paul Public Library. He was formerly in charge of the Cedar Rapids (Ia.) Public Library. Prior to that he was librarian of the Fergus Falls (Minn.) Public Library.

GARLAND R. FARMER, JR., is assistant to the director of the Hoover Institute and Library at Stanford. For the last three years he has been director of the World Affairs Council of Northern California.

James J. Heslin, formerly assistant director of libraries at the University of Buffalo, is librarian and assistant director of the New York Historical Society.

MaRy Sheldon Hopkins has been appointed librarian of the Bennington College Library, Bennington, Vermont. Miss Hopkins is a graduate of Vassar College and of the School of Library Service, Columbia University. She was assistant librarian, Webster Branch, New York Public Library before joining the staff of the Bennington College Library as assistant librarian in 1935 .

Dr. Richard G. IRwin, librarian of the East Asiatic Library and research associate in oriental languages at the University of California, Berkeley, has been awarded a Fulbright scholarship for the academic year 195657 to do research on the Chinese novel at Kyoto University, Japan.

GERALD JAHODA is group leader in the research and development department of the Colgate-Palmolive Co., Jersey City, N. J.

Patricia B. Knapp is associate professor of library science at Rosary College, River Forest, Ill. Mrs. Knapp earned her A.B. and her M.A. in library science from the University of Chicago where she is a candidate for the doctorate as well. She worked as a cataloger and later librarian at Chicago Teachers College, and as a U. S. Army librarian at Sarasota and Miami Beach. Most recently she was librarian and assistant professor of English at George Williams College.

Mrs. Ira KöIv is a member of the staff of the Engineering and Physical Sciences Library of the University of Maryland.

HaRRIET LAUBACH is reference librarian at the University of Pittsburgh.

The following appointments to the staff of the Purdue University Libraries have been made: IDA MASONE, assistant reference librarian; MARgot Moffat, assistant circulation librarian; Philip J. Schneider, assistant order librarian.

Louis D. Sass will become dean of the Library School of Pratt Institute and professor of librarianship on August 1, 1956. He has been assistant professor of librarianship at the University of California at Berkeley since 1953, following a year as lecturer there. Dr. Sass holds a Ph.D. in Philosophy from Columbia University as well as his professional library degree from the same institution. Before going to California, he held a variety of positions in the technical services departments of the City College of New York Library.

IRENE M. STRIEBY, head of the library of Eli Lilly and Company since its establishment in 1934, has the newly created post of library consultant. Louise C. LAGE, formerly assistant chief librarian, succeeds Mrs. Strieby.

David R. WATKins is head of the reference department in the Yale University Library. He was assistant reference librarian at the University of Minnesota.

\section{Foreign Libraries}

Wilhelm Braun, director of the University of Greifswald Library since 1947, retired last year at the age of 66 .

Carlos A. Bravo, noted lecturer and author, is director of the Biblioteca Nacional de Nicaragua in Managua. He succeeds RAMón ROMERo.
Albert Predeek, formerly director of the libraries of the Technische Hochschule in Berlin-Charlottenburg and of the University of Jena, died 10 February 1956. Dr. Predeek was well known in England and America for his writings on the libraries of Englishspeaking countries. 


\section{Books Received}

American College Life as Education in World Outlook. By Howard E. Wilson. Washington: American Council on Education, 1956.

Bookman's Guide to Americana. Part II-Literature. By J. Norman Heard. New Brunswick, N. J.: Scarecrow Press, 1956. 254p.

Books and Publishing, 1955. Vol. II. By Charles E. Sunderlin, David C. Mearns, Frances Lander Spain. Boston: School of Library Science, Simmons College, 1955. 55p. \$1.75. Contents."The Challenge of Scientific Literature," by Charles E. Sunderlin.- "Of More Portentous Sound:' A Codicil to Boston's Literary Testament," by David C. Mearns.-“A Mid-Century Look at Children's Books," by Frances Lander Spain.

Careers for Graduates: A Handbook of Information. Ed. for the University of London Appointments Board. London: University of London, The Athlone Press, 1956. 196p.

Directory of Libraries and Information Sources in the Philadelphia Area. 9th ed. Ed. by Geraldine $R$. James for the Special Libraries Council of Philadelphia and Vicinity, a chapter of the Special Libraries Association. Phil adelphia, 1956. 132p. (Order from Secretary, Special Libraries Council, Philadelphia.)

Gifts to the Emory University Libraries, 1945-55. Emory University, Ga., 1956. 18p.

A Guide for the Study of Exceptional Children. By Willard Abraham. Boston: Porter Sargent, 1956. \$3.50. (Porter Sargent, 11 Beacon St., Boston 8)

The Harry W. Bass Collection in Business History in the University of Oklahoma Library: As of February 20, 1956. Norman: Univ. of Oklahoma Library, 1956. 76p. (mimeo)

Libraria Magna et Libraria Parva dans la Bibliotheque universitaire du XIIIe siecle. Par H. J. de Vleeschauwer. Pretoria [University of South Africa] 1956. 60 p. (Mousaion, Nr. 7)
Library Expenditures, 1920-1955; Library Ap. propriations, 1944-1956. Lincoln: University Libraries, University of Nebraska, 1956. 48 p. (Cornhusker Librarian, No. 18)

List of Subject Headings for Small to Medium Sized Law Libraries (Mainly Anglo-American). Comp. by Helen McLaury. Chicago: Northwestern University School of Law, 1956. 97p.

The Papers of Cornelius Cole and the Cole Fam. ily 1833-1943: A Guide to Collection 217. Ar. ranged, annotated, and indexed by Elmo $\mathbf{R}$. Richardson. Los Angeles: University of California Library, 1956. 53p. (UCLA Library Occasional Papers, No. 4)

Political Handbook of the World, 1956. Ed. by Walter H. Mallory. New York: Harper, 1956. 228p. \$3.75. (Published for the Council on Foreign Relations)

Proceedings of the World Symposium on Applied Solar Energy, Phoenix, Arizona, Novem ber 1-5, 1955. Sponsored by the Association for Applied Solar Energy, Stanford Research Institute, University of Arizona. Menlo Park, Calif.: Stanford Research Institute, 1956. 304p. $\$ 5$.

The Religious Press in the South Atlantic States, 1802-1865: An Annotated Bibliography with Historical Introduction and Notes. By Henry Smith Stroupe. Durham, N. C.: Duke University Press, 1956. 172p. $\$ 4.50$.

Toynbee and History: Critical Essays and Reviews. Ed. by M. F. Ashley Montagu. Boston: Porter Sargent, 1956. 385p. $\$ 5$.

Union List of Serials of Government Agency Libraries of the Philippines. Comp. by the Staff of the Inter-Departmental Reference Service, Institute of Public Administration, University of the Philippines. Manila, 1955.623p.

University Library Problems; Dedicated to Dr. $P$. C. Coetzee. Pretoria [University of South Africa] 1955.87 p. (Mousaion, Nr. 5-6)

The Library of Congress has published Herbert Putnam, 1861-1955, a Memorial Tribute. Putnam was Librarian of Congress from 1899 to 1939 when he became Librarian Emeritus, a post he held until his death last summer. This book on one of America's great librarians is largely the work of David C. Mearns, Library of Congress historian and biographer of Dr. Putnam. 